Zbigniew A. SZYDŁO ${ }^{1}$

\title{
HISTORY OF FIRE
}

\author{
HISTORIA OGNIA
}

\begin{abstract}
The history of fire is an important and fascinating topic, yet it is not covered in any school or university syllabus. In the present article, the author argues a case for its inclusion in chemistry teaching programs. He outlines some key points relating to investigations on the nature of combustion processes and the discovery of oxygen. Details are included for a class experiment with gunpowder, which is suitable for school pupils aged 13 to 15 .
\end{abstract}

Keywords: fire, combustion, respiration, nitre, element, air, experiment

\section{Introduction}

The yellow flame represents one of the greatest achievements of early civilizations. In East Africa and Australia some 100,000 years ago, people were able to make flames, and to sustain them. They were made by either striking flints or rubbing wooden sticks to generate the necessary temperature for ignition, by friction. For thousands of years this was the only type of flame known to humans.

About 250 years ago it was experimentally proven that air is a mixture of gases. Its two main constituents were shown to be nitrogen $(\approx 80 \%)$ and oxygen $(\approx 20 \%)$, with oxygen being the gas which was necessary for both respiration and burning. This apparently simple fact had a profound effect and played a key role in the emergence of the Industrial Revolution.

None of the following inventions would have been possible without a knowledge of the air's composition: motor cars, aeroplanes, gas cookers, central heating systems, modern rockets and ships, and high explosives. To these we can add the ubiquitous Bunsen Burner, found in school chemistry laboratories. Remarkable developments in our lifestyles have been made, since through our knowledge of the composition of air, we can optimize the burning of fuels and exploit them efficiently in combustion engines. Figures 1 and 2 show the appearance of flames during incomplete combustion (yellow - inefficient) and complete combustion (blue - efficient).

\footnotetext{
${ }^{1}$ Highgate School, London, United Kingdom, email: andrew.szydlo@ highgateschool.org.uk
} 


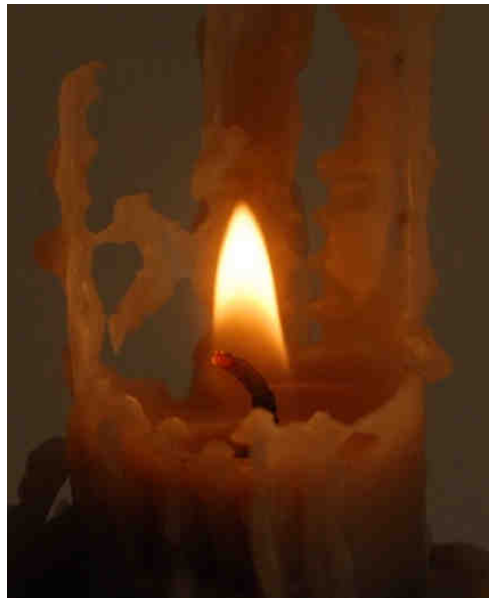

Fig. 1. Candle flame, known for thousands of years - incomplete combustion

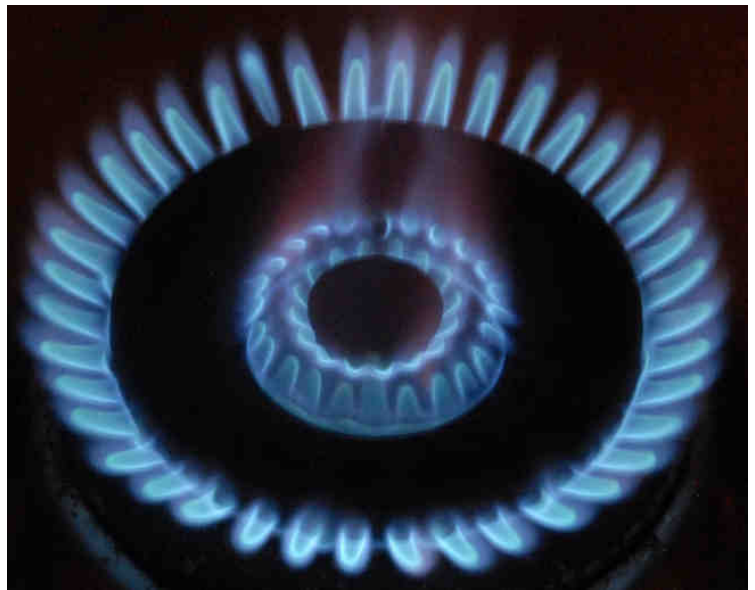

Fig. 2. Gas cooker flame, known for 200 years - complete combustion

The enormous significance of the history of events which led to the discovery of oxygen cannot be overemphasized. Yet in chemistry teaching programs no mention is made of the historical background of combustion. The following account throws some light on this extraordinary story.

\section{Historical highlights}

From time immemorial, air was considered a single substance, since it never appeared to be a mixture. It was one of the four elements - earth, fire, air and water, which had been initially suggested by Empedocles of Agrigentum in Sicily [495-435 BC], and subsequently became incorporated as part of a grand philosophical system which explained 
natural phenomena, by the Greek philosopher Aristotle [384-322 BC]. This system formed the basis of alchemy which was an early experimental science.

Although Aristotle's system seemed to be convincing, many questions remained unanswered and unexplained. One of these was the phenomenon of fire. The Greek engineer Philo of Byzantium [280-220 BC] conducted an experiment in which he burned a candle in an enclosed space, and the flame became extinguished. His explanation of this observation left many unsolved questions, and it sparked off a great interest in the process of combustion. Even though burning remained a mystery, significant improvements in this process were made by people who lived a long time ago.

During the Bronze Age $(\approx 10,000$ years ago), the Hittites and Assyrians were able to achieve high temperatures in fires by blowing in extra air by means of bellows. The reason for the increased temperatures was not known or understood, but the use of bellows to supply extra air enabled metals to be smelted.

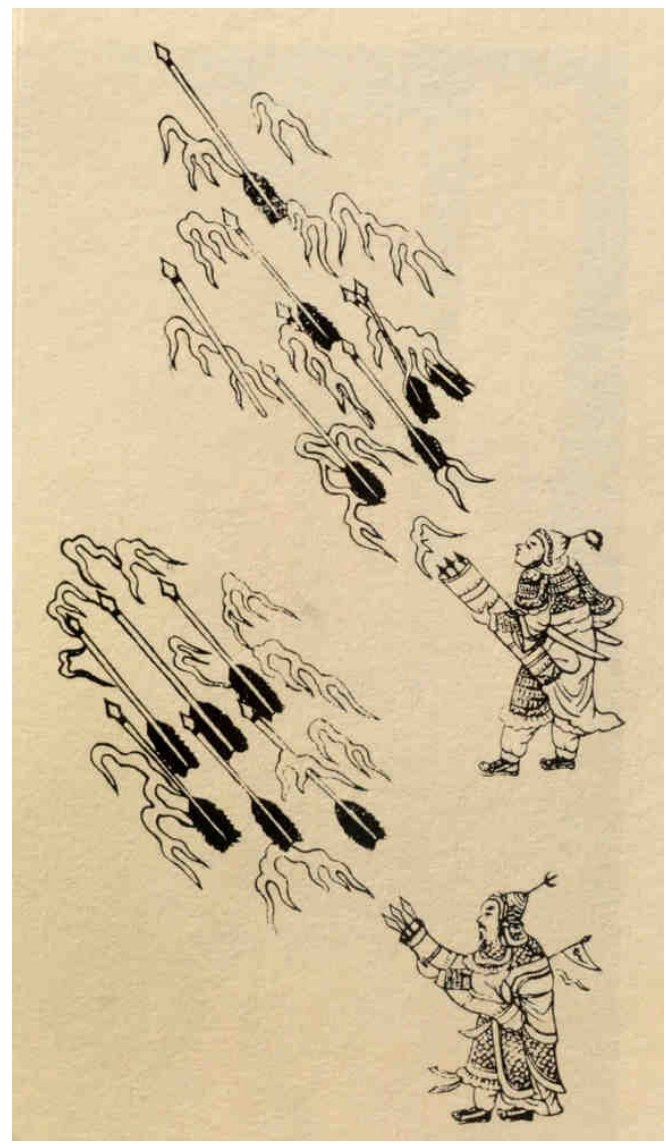

Fig. 3. Chinese firework rockets, circa 1400 [1]

The discovery of gunpowder by the Chinese evolved over several centuries and this was another great step forward in the quest for improving flames. About 1000 years ago 
pyrotechnic devices were widely used in China. Figure 3 shows rockets being launched from portable basket carriers. They had a range of about 200 metres and the arrows, attached to the rockets, were tipped with poison. Many thousands of these rockets could be fired in one battle.

Chinese scientific and technical knowledge gradually diffused westwards: in the $13^{\text {th }}$ century the English Franciscan friar and natural philosopher Roger Bacon [1219-1292] also successfully made gunpowder and described its composition.

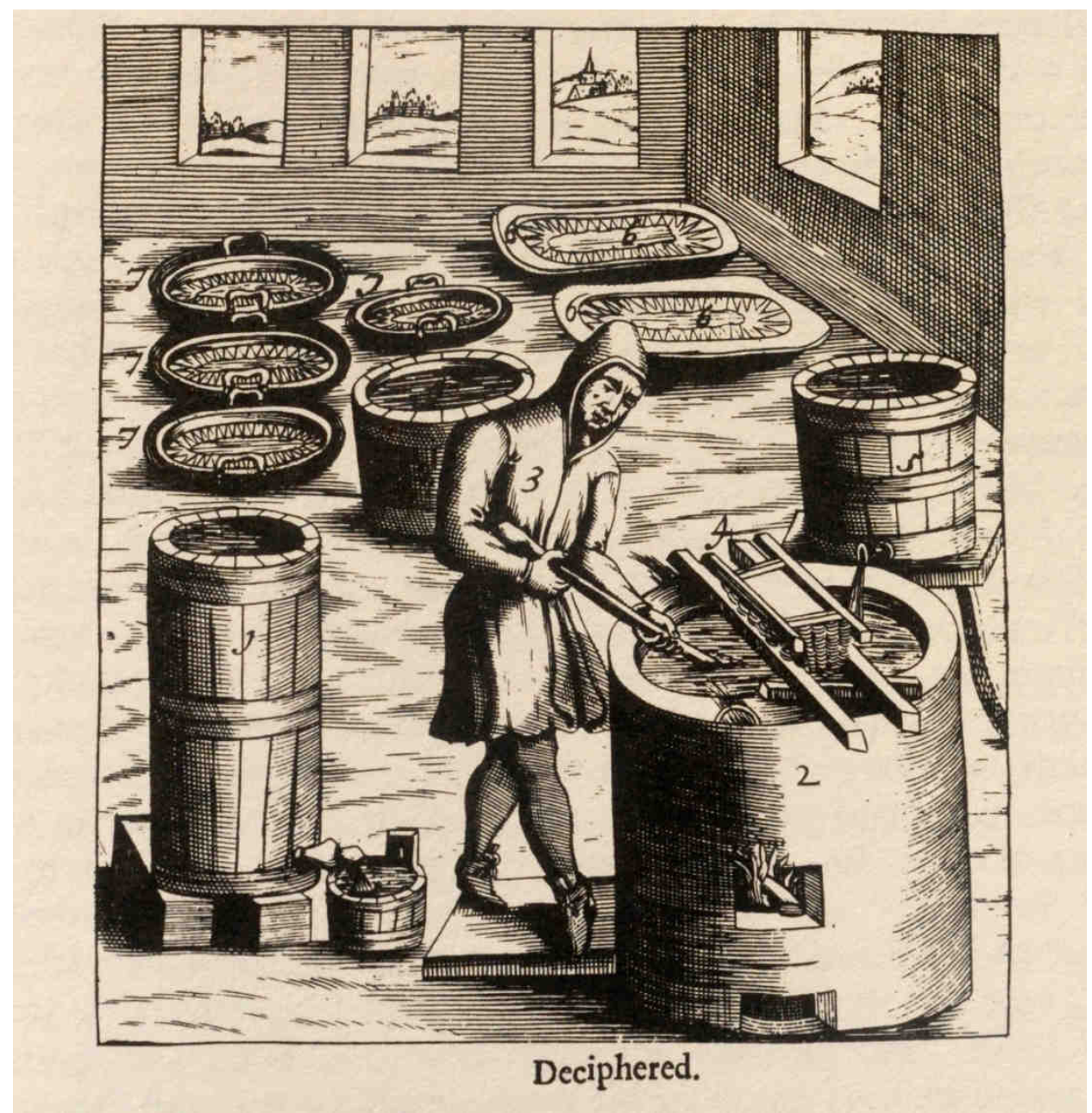

Fig. 4. Purification of nitre by crystallization. This illustrates the relatively large scale of the saltpetre industry in $16^{\text {th }}$ century Europe [2]

Early efforts which led to the discovery of gunpowder were conducted on an empirical basis. This means that intuition and experience were used to make progress. No-one really understood why or how gunpowder worked. But it was known that the key ingredient was 
potassium nitrate, then known by a variety of names such as nitre, philosopher's nitre, saltpetre, central salt nitre. Where did the nitre come from? It is formed naturally (biologically and chemically) in soils, from cattle urine and wood ash. In China and India, the warm moist climate favoured the formation of nitre, which grew as white crystals, out of soils on which cattle urinated. Interestingly, India was a leading exporter of naturally made potassium nitrate until the end of the $19^{\text {th }}$ century. Nitre was manufactured on a large scale in Europe from the $14^{\text {th }}$ century onwards. Most of it was used for making gunpowder for use in warfare. Figure 4 illustrates an early industrial process involving the crystallization of nitre from its saturated solution. Figure 5 shows the actual appearance of crystals of nitre which have been grown from a saturated solution of potassium nitrate.

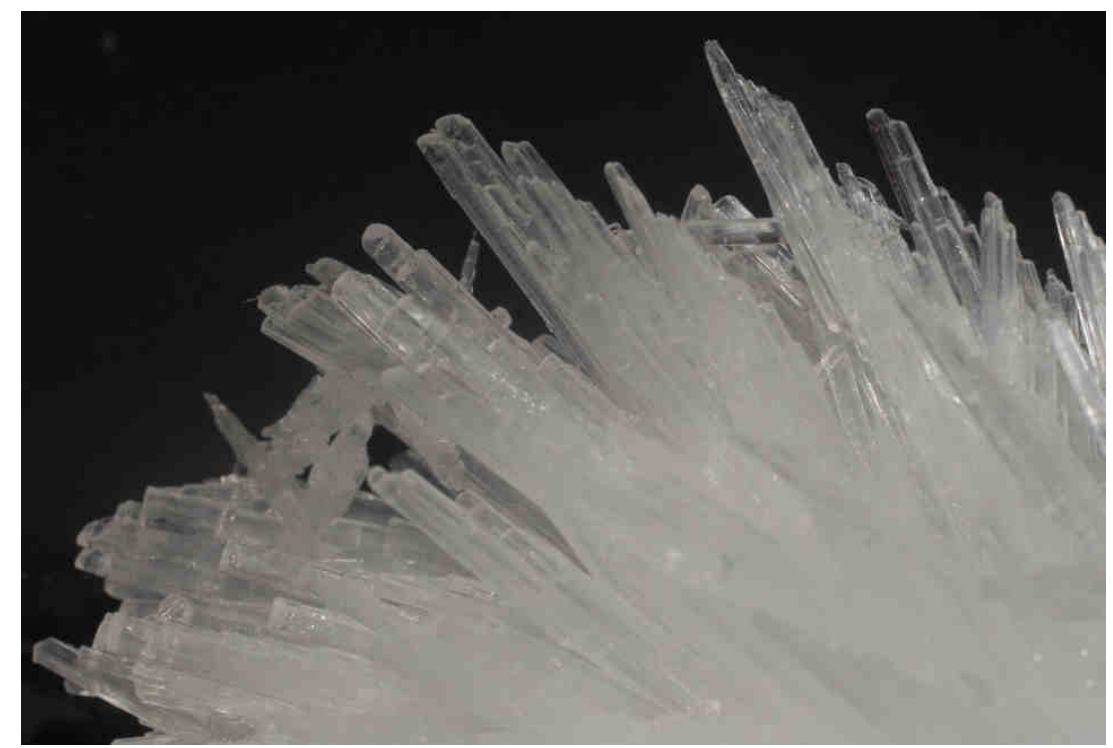

Fig. 5. Nitre crystals, freshly grown from a saturated solution

Throughout the ages, alongside technical innovations which were based on trial and error, there evolved a theoretical approach whose aim was to explain natural phenomena. During the sixteenth and seventeenth centuries, the combination of the theoretical with the practical gave birth to modern experimental science. Experiments were conducted, whose sole aim was to seek an explanation of natural phenomena.

Among the great unexplained mysteries of nature were thunderstorms. The Swiss physician and alchemist Philippus Theophrastus Aureolus Bombast von Hohenheim, otherwise known as Paracelsus [1493-1541], attempted to explain thunder and lightning by postulating the existence of an "aerial" nitre, present in the air, which caused it to explode like gunpowder. He lived at a time when experimental science was still in its infancy, and hence his ideas were drawn from a more ancient world view - that of correlation and analogy, rather than experiment and deduction. His philosophy of Nature made good sense at that time, and the "aerial nitre" of thunderstorms inspired the next generation of natural philosophers. 
One of these was the secretive Polish alchemist Michał Sędziwój (Michael Sendivogius) [1566-1636]. He was educated at Leipzig and Vienna universities, and became a competent practitioner of the alchemical arts. He became employed at the court of Emperor Rudolph II in Prague in 1594 and was active there for about 10 years.

In 1604 Sendivogius published his first work in Prague. It was entitled: De Lapide Philosophorum Tractatus Duodecim, é Naturae fonte, et Manuali Experientia deprompti. Autor sum, qui DIVI LESCHI GENUS AMO. Anno M.DC.IV. (Twelve treatises on the Philosopher's Stone. Taken from the fountain of nature and manual experience. I am the author who loves the divine race of the Lechites. 1604) This turned out to be a remarkably successful and influential work: between 1604 and 1787, 56 editions in 5 languages were published under a shortened title: Novum Lumen Chymicum (A new chemical light). Figure 6 shows the title page of the 1674 English language edition of his New Light of Alchymy. It was studied by both Isaac Newton [1643-1727] and Antoine Lavoisier [1743-1794].

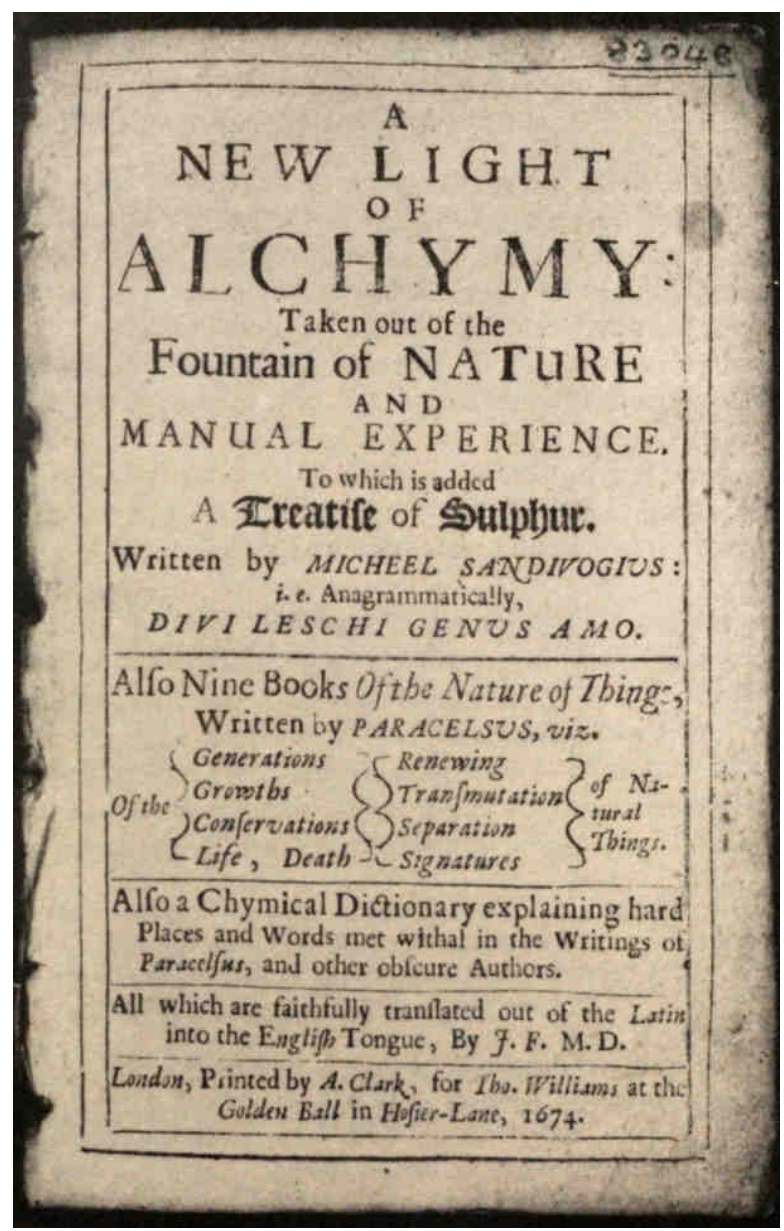

Fig. 6. Title page of the second English edition of Sendivogius' most widely read work, A New Light of Alchymy. Published in 1674 and translated by John French. [Courtesy of the Wellcome Institute Library, London] 
An important reason for the great interest which this alchemical work generated, was that it was based on experiments. On the title page is clearly stated: "Taken out of the Fountain of nature and manual experience." Sendivogius drew attention to a hitherto unrecognised aspect of air: it plays a key role in life processes. He was able to link this to the properties of nitre which was a key component of gunpowder. The following short passages which are translations from the Epilogue of his first edition of 1604, illustrate the novelty of his ideas:

"Man is made of earth, and lives through air; for air contains the hidden food of life, of which the invisible spirit, when congealed, is better than the whole world...

This is the water of our dew, which is extracted from the saltpetre of the Sages, by which all things grow, exist and are nourished...

Our substance is openly displayed before the eyes of all, and yet is not known. Oh, how marvellous is our heaven, and our water, and our saltpetre which are in the world sea...

our water that does not wet the hands, and without which no mortal can live - without which nothing is born or generated in the whole world!" [3]

The interpretation of these fragments is not easy, since alchemical texts were written in an occluded style. Yet a detailed analysis of the Sendivogian writings reveals that his theory of an aerial substance that is necessary for life can be explained in modern scientific terms. Figure 7 shows a diagrammatic representation of this theory - it combines the traditional alchemical world-view which was based on analogy, with one which can be interpreted in terms of known chemical compounds.

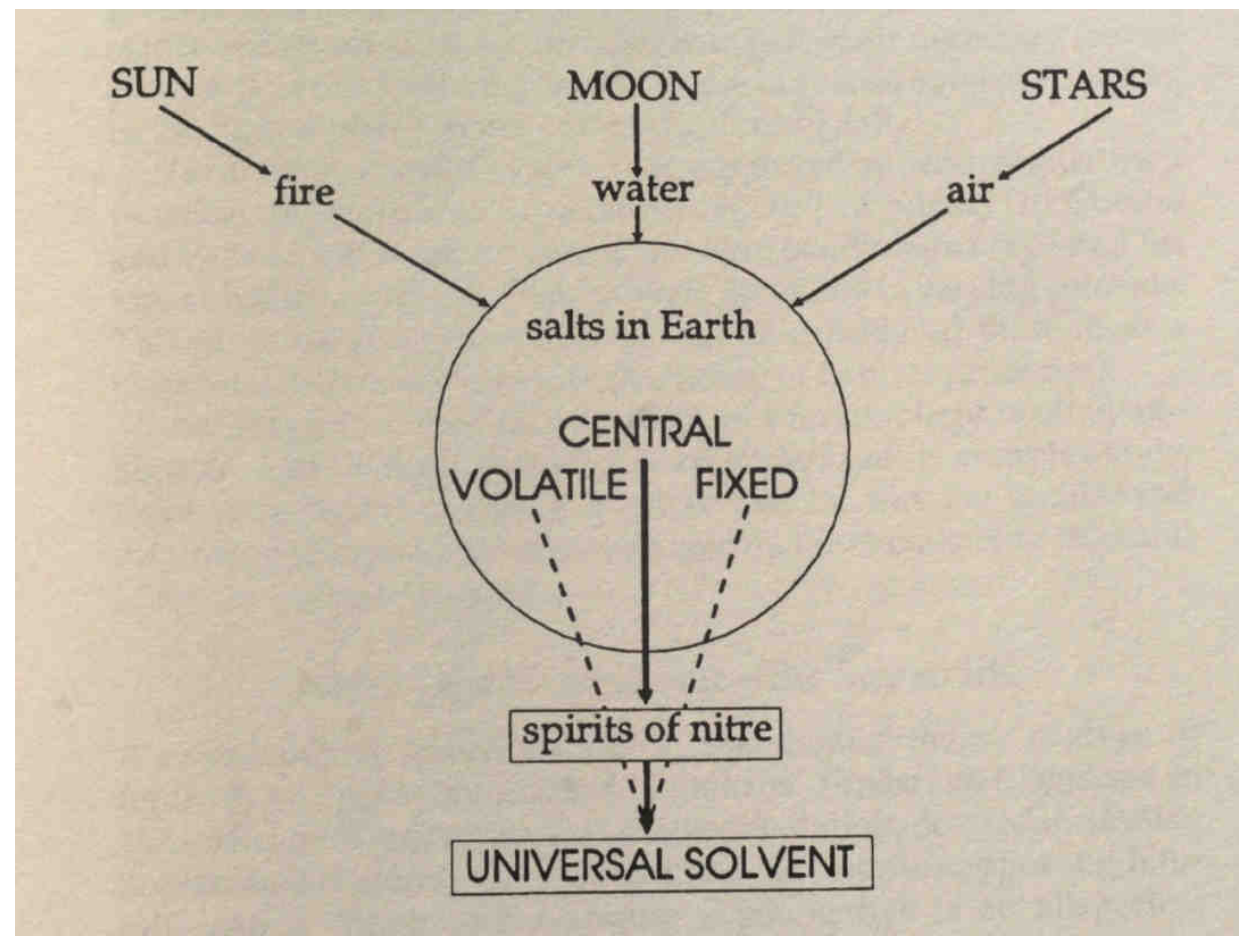

Fig. 7. A diagrammatic representation of Sendivogius' Central Nitre theory [4] 


\section{Interpretation of the diagram}

1. Nature produces the Central Salt which plays a vital role in the life cycles of plants and animals.

2. Man uses the Central Salt to produce the universal solvent from which the universal seed of metals can be formed - this enables the transmutation of base metals into gold to take place.

3. The Central Salt provides a link between "what is up there" and "what is down below". (This was an important idea in the world of the alchemical philosophy - it stemmed from the 2nd precept of the Tabula Smaragdina [Emerald tablet] of the legendary Hermes Trismegistos). The Central salt, or potassium nitrate, thus provides the key to all phenomena relating to life. Modern chemical interpretation: central salt $=$ potassium nitrate, volatile salt $=$ ammonium chloride, fixed salt $=$ potassium carbonate, spirits of nitre $=$ nitric acid, universal solvent $=$ aqua regia $($ a mixture of concentrated nitric and hydrochloric acids).

An important aim of alchemical experiments had been to seek the Philosopher's Stone which would transmute base metals into gold. The Sendivogian theory initiated a new wave of interest in air, particularly at Oxford University during the middle decades of the $17^{\text {th }}$ century. Pioneers of air pressure investigations (physics) had included the Italians Galilei Galileo [1564-1642] and Evangelista Torricelli [1508-1647]. Robert Boyle [1627-1691] was an Irish natural philosopher who developed a great interest in both the physical and chemical properties of air during the 1650s. Experiments on the changes which occurred in air during breathing and burning (chemistry) were conducted by Thomas Willis [1621-1675] and Robert Hooke [1635-1703], among many others. It had been well-known for a long time that when substances burn, an inexplicable change occurs in air - it becomes unable to support further combustion or indeed, any form of animal or insect life. This change was difficult to explain because air was thought to be an element, that is a single substance.

Ingenious experiments and apparatus were devised to try to explain what happens when animals breathe and substances burn. Boyle investigated the combustion of gunpowder, for example, by igniting samples of it in an evacuated container, by means of a large magnifying glass. Over a period of many years he conducted countless experiments which he documented in his book - The Sceptical Chymist (Oxford, 1661). In it he debated the exact meaning of the word ELEMENT. This is because he had found the Aristotelian philosophy, based on the four elements: Earth, Fire, Air and Water, highly unsatisfactory. Boyle gave today's definition of an element as: a substance which cannot chemically be broken down into simpler substances.

During his research into the properties of air, Boyle became fascinated by an unusual event - the underwater journey of a wooden vessel in 1620. This had been designed for King James I [1566-1625] by the secretive Dutch inventor, Cornelis Drebbel [1572-1633]. The submarine had been propelled from Westminster to Greenwich by 12 rowers, and Drebbel had reputedly freshened the air in the vessel with a secret mysterious "liquor". This became the main focus of Boyle's interest: "Drebell conceiv'd, that 'tis not the whole body of the Air, but a certain Quintessence (as Chymists speake) or spirituous part of it, that makes it fit for respiration, which being spent, the remaining grosser body, or carcase (if I may so call it) of the Air, is unable to cherish the vital flame residing in the heart." [5]. 
Figures 8 and 9 show a recent historical reconstruction of a two-man version of Drebbel's submarine.

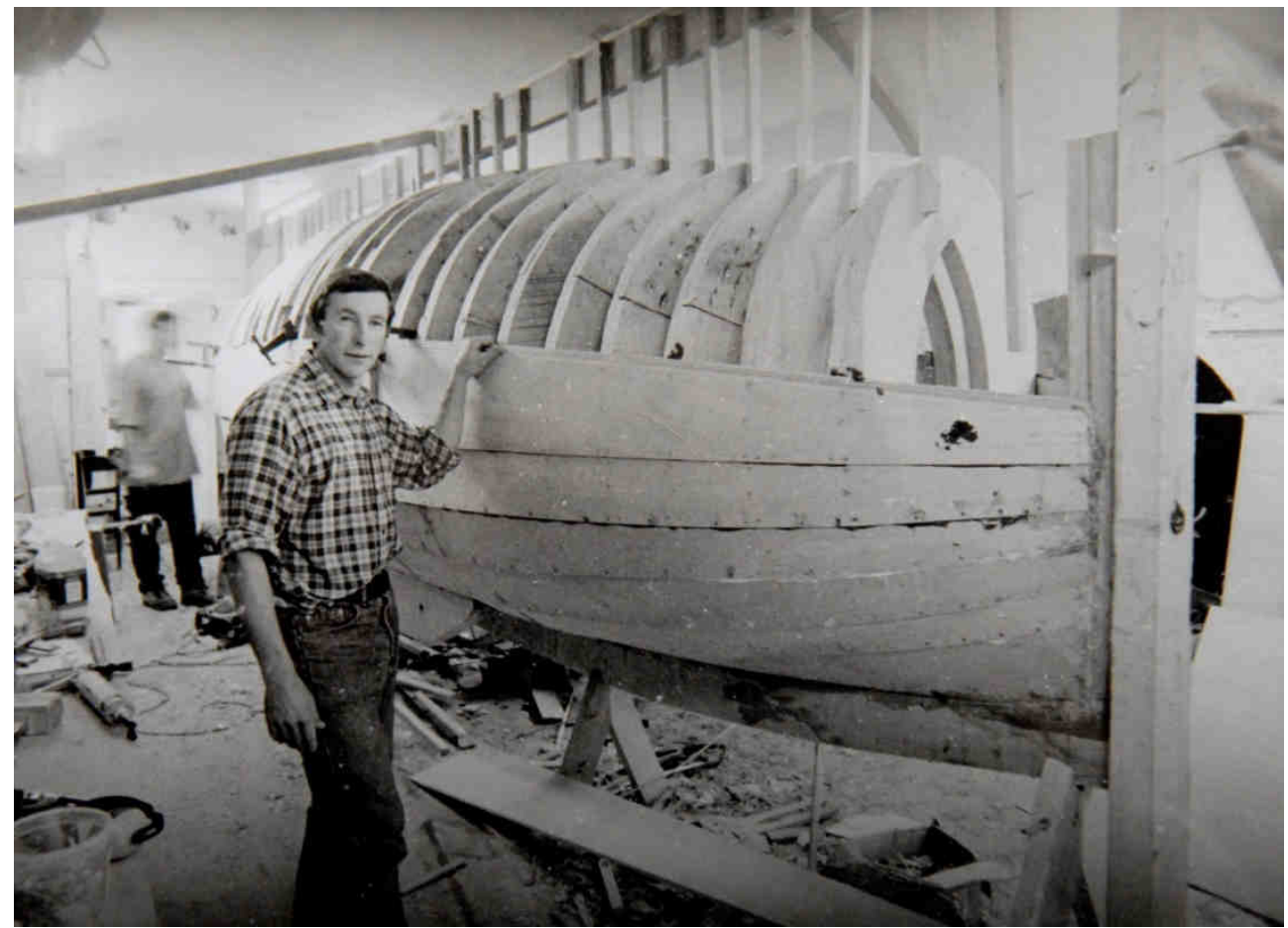

Fig. 8. Historical reconstruction of Drebbel's submarine by Mark Edwards. The submarine was built in 2001, for a documentary film about Drebbel

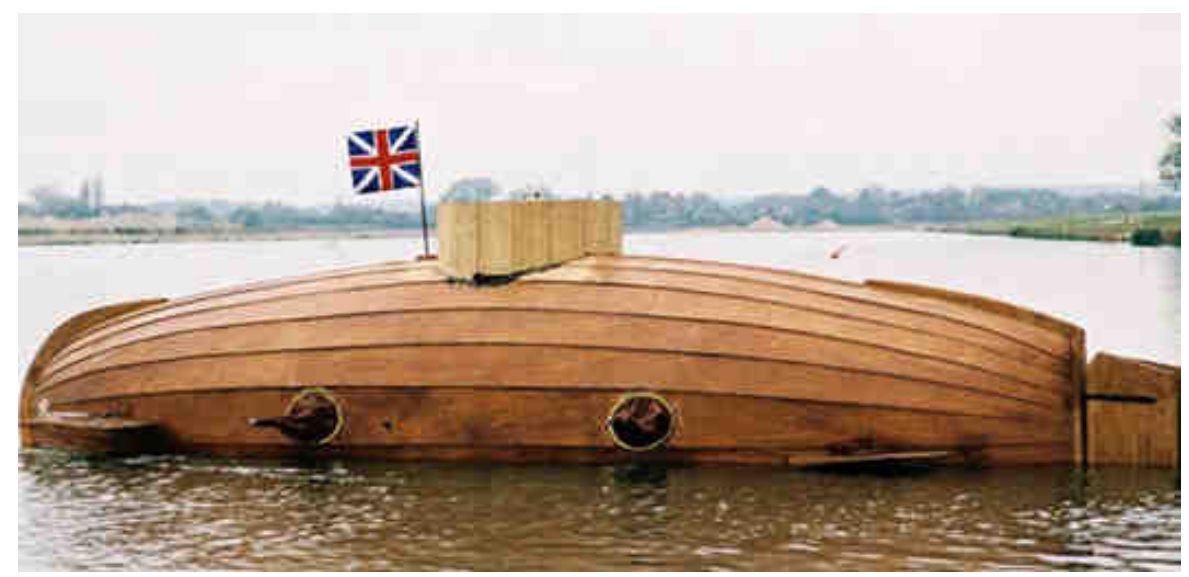

Fig. 9. The submarine sets sail - it was successfully tested by its two-man crew in the river Thames, near Eton, in 2002 
It is possible to gain some insight into Drebbel's technique for freshening the air in the submarine, by consulting his Treatise on the Elements of Nature, which was first published in 1608, four years after the appearance of Sendivogus' Novum Lumen Chymicum. In a passage on the origin of thunder he wrote: "saltpeter, gebroken door der kracht des vuurs, en alzoo verandred in der natuur der lucht (thus is the body of the saltpetre broken up and decomposed by the power of the fire and so changed in the nature of the air)..." [6]. Nearby is included a diagram of a retort flask being heated. Several versions of this illustration were published. In Figure 10, from the 1688 Dutch edition of Drebbel's work, two men are seen gazing at bubbles emerging from the spout of a retort flask in a ceramic trough of water. The experiment could represent the thermal decomposition of nitre (potassium nitrate), the gaseous product ( $\mathrm{g}$ ) of which we would recognise today as oxygen.

$$
2 \mathrm{KNO}_{3}(\mathrm{~s}) \rightarrow 2 \mathrm{KNO}_{2}(\mathrm{~s})+\mathrm{O}_{2}(\mathrm{~g})
$$

$$
\text { potassium nitrate } \rightarrow \text { potassium nitrite }+ \text { oxygen }
$$

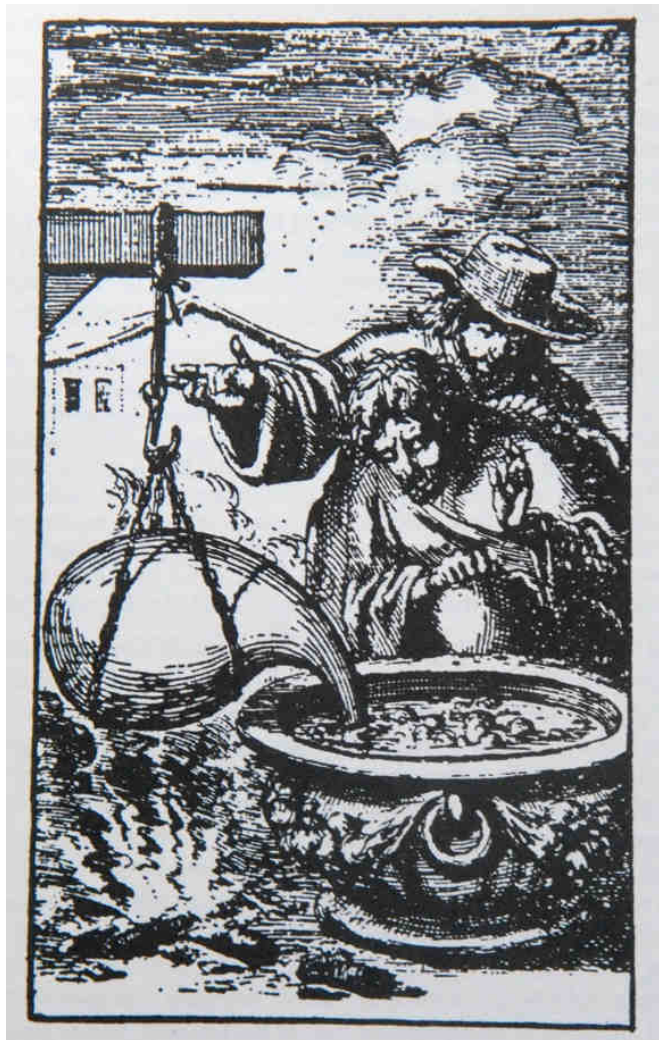

Fig. 10. Drebbel's experiment - the thermal decomposition of nitre? [6]

The question arises: from where did Drebbel get this extraordinary idea? Extraordinary, since it implies that he knew how to make oxygen. At the beginning of the $17^{\text {th }}$ century, Drebbel had been employed as an engineer, inventor and pyrotechnician at the 
court of the Habsburg monarch Emperor Rudolph II [1552-1612] in Prague, alongside numerous alchemists, natural philosophers, doctors, astronomers, magicians and astrologers. In essence, Rudolph II, who was a great enthusiast and patron of the arts, occult and sciences, had created in central Europe a great melting pot of interesting and diverse people. Drebbel and Sendivogius were two of them. Whilst no proof is available, it is quite possible that they knew one another and were able to exchange ideas. Drebbel could thus have gained a knowledge of nitre and its life-giving properties.

John Mayow [1641-1679] was a younger contemporary of Boyle, and he too advanced our understanding of the role of air in respiration and combustion, and brought the topic to the forefront of the scientific agenda of the day. Figure 11 shows details of some of his experiments and apparatus.
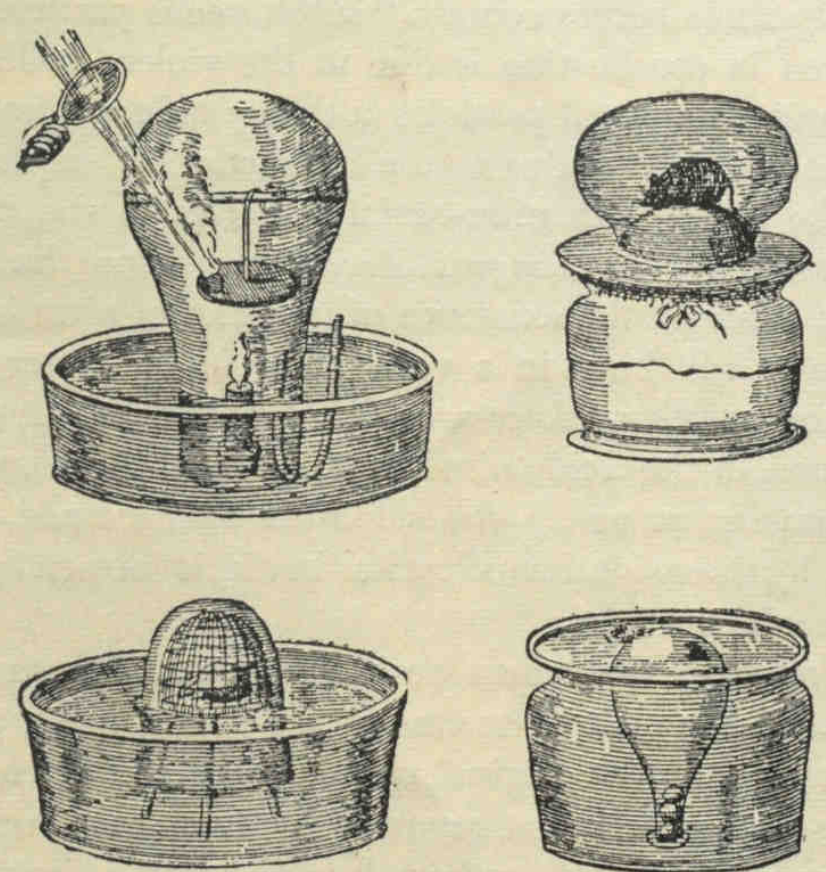

Fig. 40.-MAYOW'S EXPERIMENTS (I674).

The Illustrations Depict the Experiments ON COMBUStion AND ON THE Respiration of a MOUSE Described in the text; also the Contraction OF AIR CONFINED OVER WATER By the RESPIRATION OF a MOUSE, AND THE

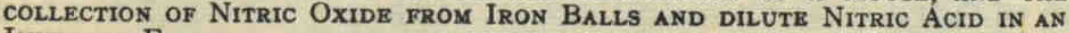
INVERTED FLASK.

Fig. 11. Mayow's experiments and apparatus [7]

In his Tractatus Quinque Medico-Physici (Oxford, 1674), Mayow explained the processes of combustion and respiration in terms of particles - igneo aerial and nitro aerial. Particles had been introduced into the chemical philosophy by Rene Descartes [1596-1650] during the $1630 \mathrm{~s}$, and they played a significant role in the development of scientific ideas during the $17^{\text {th }}$ century. This subsequently led to the development of John Dalton's 
[1766-1844] epoch making atomic theory at the beginning of the $19^{\text {th }}$ century. The following passage is taken from the Tractatus Quinque: "Besides, the nitro-aerial salt, whatever it may be, becomes food for fires, and also passes into the blood for respiration, as will be shown below. Also, Further, it is impossible that these igneo-aerial particles are any perfect nitre, as is generally supposed - for it was already pointed out that not the very nitre as a whole, but only a certain part of it, resides in the air..." [8]. It is possible to see the influence of Sendivogian ideas here, because of the references to nitre and air.

It was particularly difficult in those times to understand how a gaseous substance (oxygen) could be chemically combined (fixed) as part of a solid - potassium nitrate. The word "gas", derived from the ancient Greek word "chaos", was first used in 1624 by the Flemish iatrochemist Johannes Baptista van Helmont [1580-1644]. With hindsight, it is possible to see that Mayow was talking about chemical processes involving oxygen, and oxidation reactions. He was close to a recognition of a substance found in air, which supports respiration and combustion, which we recognise today as the element oxygen.

Although the discovery of oxygen and its role in combustion and respiration seemed imminent, another theory relating to burning caught the imagination of chemical philosophers for almost 100 years. This was the phlogiston theory which was formulated in 1667. It stemmed from observations of the combustion of metals and was the brainchild of two German chemical philosophers: Georg Ernst Stahl [1660-1734] and Johann Joachim Becher [1635-1682]. According to their theory, all substances contain a combustible principle called phlogiston (from the Ancient Greek, meaning "burnt up"). When they burn, phlogiston is released into the air. The theory did not explain however, why metals became heavier when they were burnt. This was overcome by the suggestion that phlogiston had negative mass. Although this theory raised several questions, it was nevertheless instrumental in the development of the important lead chamber process for the manufacture of sulphuric acid in 1746 .

One of the earliest teachers of chemistry (which had become established as a branch of natural science towards the end of the $17^{\text {th }}$ century) was the Fleming Hermann Boerhaave [1668-1738]. He saw Sendivogius' discovery as a crucial step towards an understanding of the nature of air. In his textbook of chemistry, the first such work, Elementa Chemiae, (Lugduni Batavorum, 1732), he wrote: "air possesses a certain occult virtue which cannot be explained by any of those properties previously investigated. That in this virtue the secret food of life lies hidden, as Sendivogius clearly said, some chemists have asserted. But what it really is, how it acts, and what exactly brings it about is still obscure. Happy the man who will discover it!" [9]

Throughout the first decades of the 18th century, gases became recognised as substances with specific chemical and physical properties. Yet their investigation was problematic since it was difficult to collect samples of them. With the publication in 1727 of Stephen Hales' [1677-1761] Vegetable Staticks, a great breakthrough was made in practical techniques - the collection of gases by the displacement of water was described. The era of pneumatic chemistry was thus born. The new method of handling gases enabled them to be studied in more detail than had previously been possible. Other techniques for collecting gases included animal (pig, calf, ox) bladders, and by displacement of mercury.

Joseph Priestley [1733-1804] was a sickly child and his education was neglected for some time. He subsequently learnt Hebrew, Latin and Greek, studied theology and became a nonconformist minister. As a young man he developed a passionate interest in experimental science. Two invisible phenomena had grabbed the attention of scientists at 
that time: electricity (a form of energy) and gases (substances). Priestley became involved in both and was an exceptionally skilled manipulator of gases - Figure 12 shows some of his apparatus for the collection and storage of gases. When in 1774 he discovered a new gas which supported both combustion and respiration, he called it dephlogisticated air.

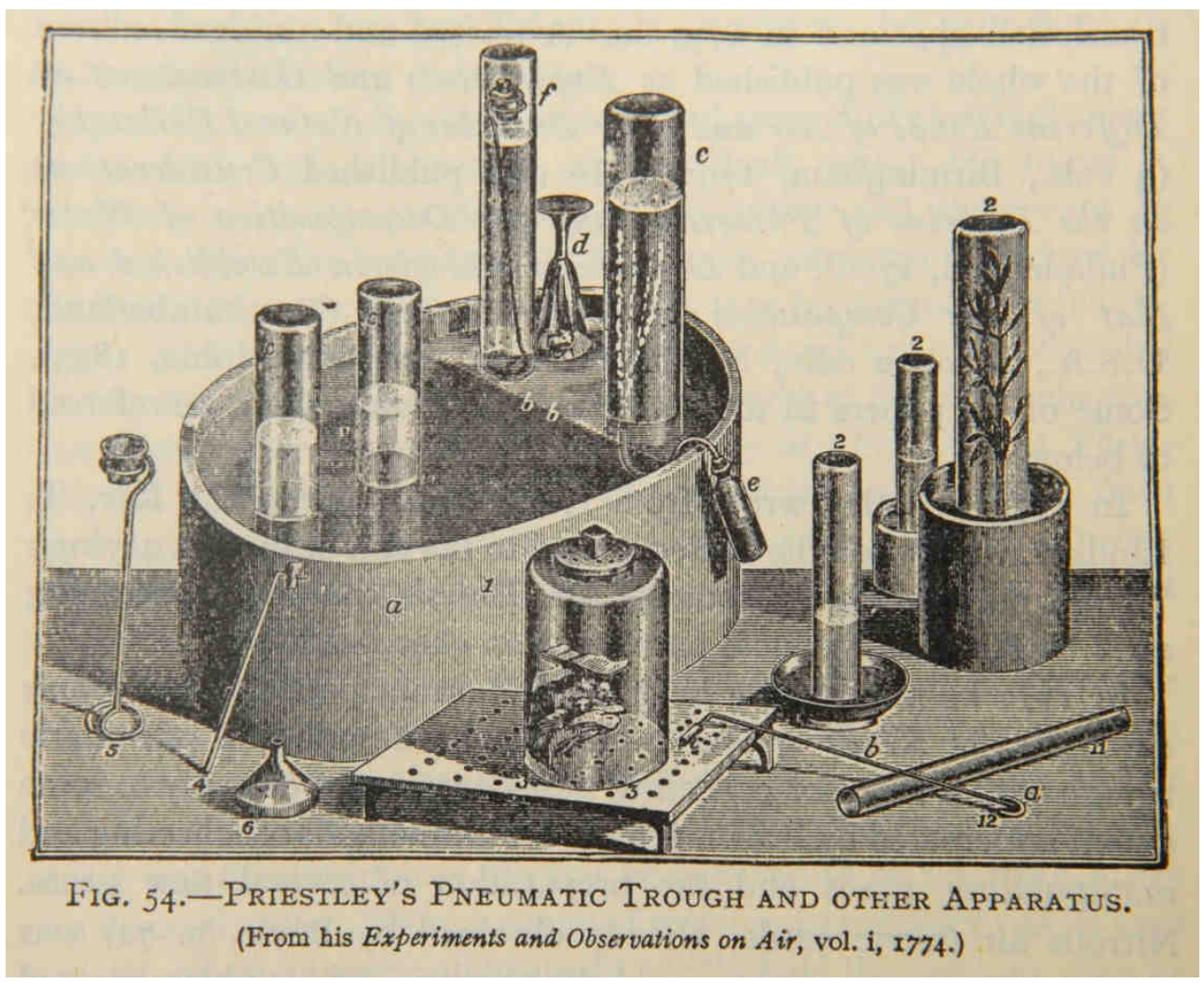

Fig. 12. Priestley's apparatus for collecting gases and investigating their properties [7]

He made the gas by strongly heating the calx of mercury, which today is called mercury (II) oxide, in the reaction which represents its thermal decomposition.

The equation for the decomposition of mercuric oxide (solid, (s)) is given today as:

$$
\begin{gathered}
\text { mercuric oxide } \rightarrow \text { mercury }+ \text { oxygen } \\
2 \mathrm{HgO}(\mathrm{s}) \rightarrow 2 \mathrm{Hg}(\mathrm{l})+\mathrm{O}_{2}(\mathrm{~g})
\end{gathered}
$$

This is an interesting reaction since it contains all 3 states of matter, unusually the liquid (l) state is not water. The question arises - why would Priestley be doing such an experiment? He had started to realise that air was possibly not "unalterable" and was trying to extract different kinds of "air" by strongly heating a variety of solids which he had been given. One of these was the calx of mercury.

Figure 13 shows a late $19^{\text {th }}$ century artist's impression of Priestley's experiment. This impression is unrealistic for a number of reasons: the experimenter would have to hold 
the glass for an hour or two in order to collect a sensible yield of oxygen, the inverted glass phial AB would need a support, and the dimensions are wrong. Priestley wrote: “...having ... procured a lens of twelve inches diameter, and twenty inches focal distance" [10], whereas in the illustration, the dimensions are clearly different!

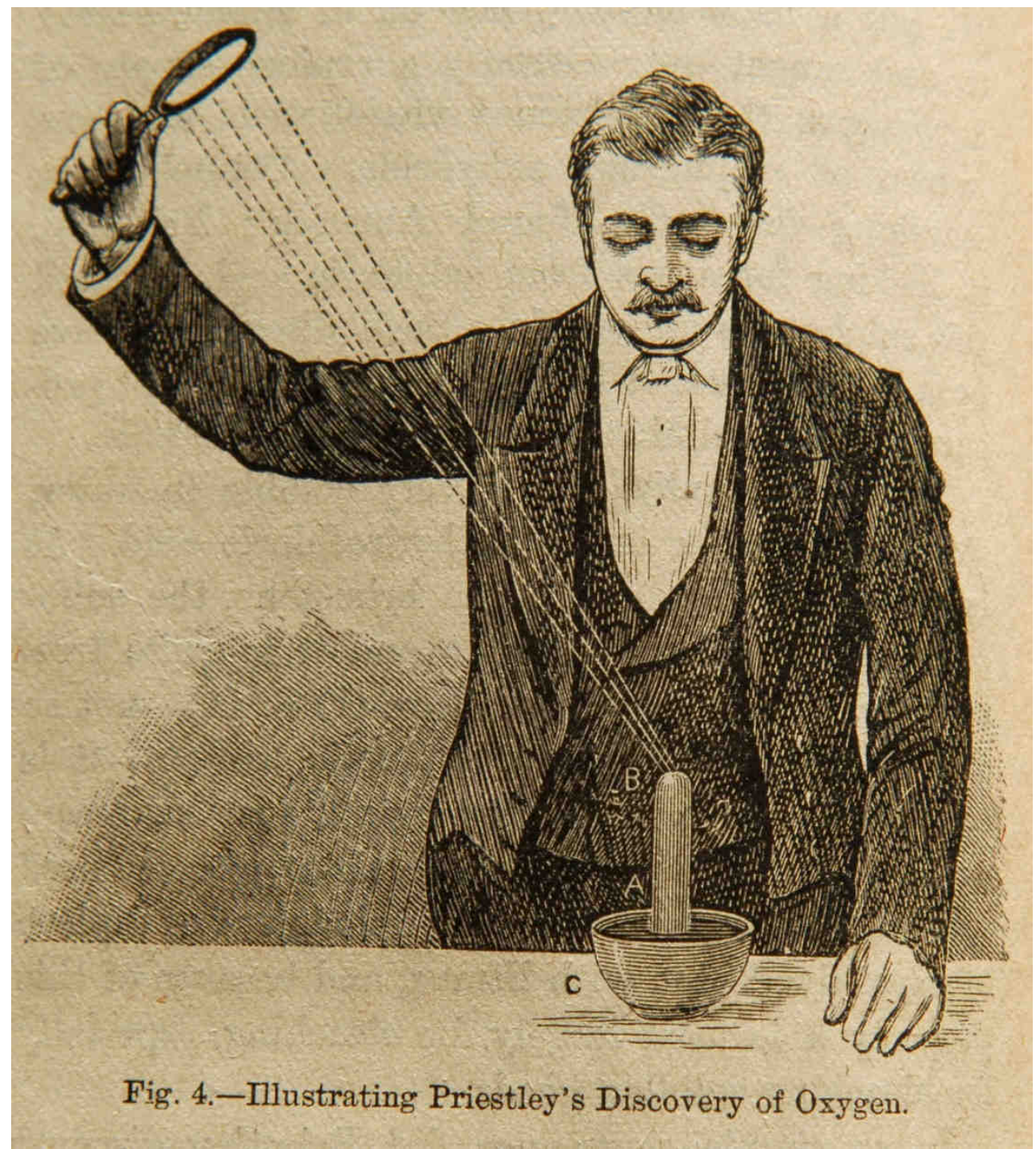

Fig.13. Artist's impression of Priestley's experiment [11]

Priestley was delighted with this experiment, and after he had breathed some of the new gas, he wrote in his diary that his breast felt: “...peculiarly light and easy for some time afterwards. Who can tell but that, in time, this pure air may become a fashionable 
article in luxury. Hitherto only two mice and myself have had the privilege of breathing it... Nothing I ever did has surprised me more or is more satisfactory." [10]

When the Swedish apothecary Carl Wilhelm Scheele [1742-1786] discovered the same gas by the same chemical reaction in 1772, he called it feuerluft (fire air). His reason for doing the experiment, which was conducted two years before Priestley (but published after Priestley) was to see whether he could separate heat, which was considered to be a material substance, into its constituents: fire air and phlogiston. He employed a variety of different types of apparatus some of which are shown in Figure 14.

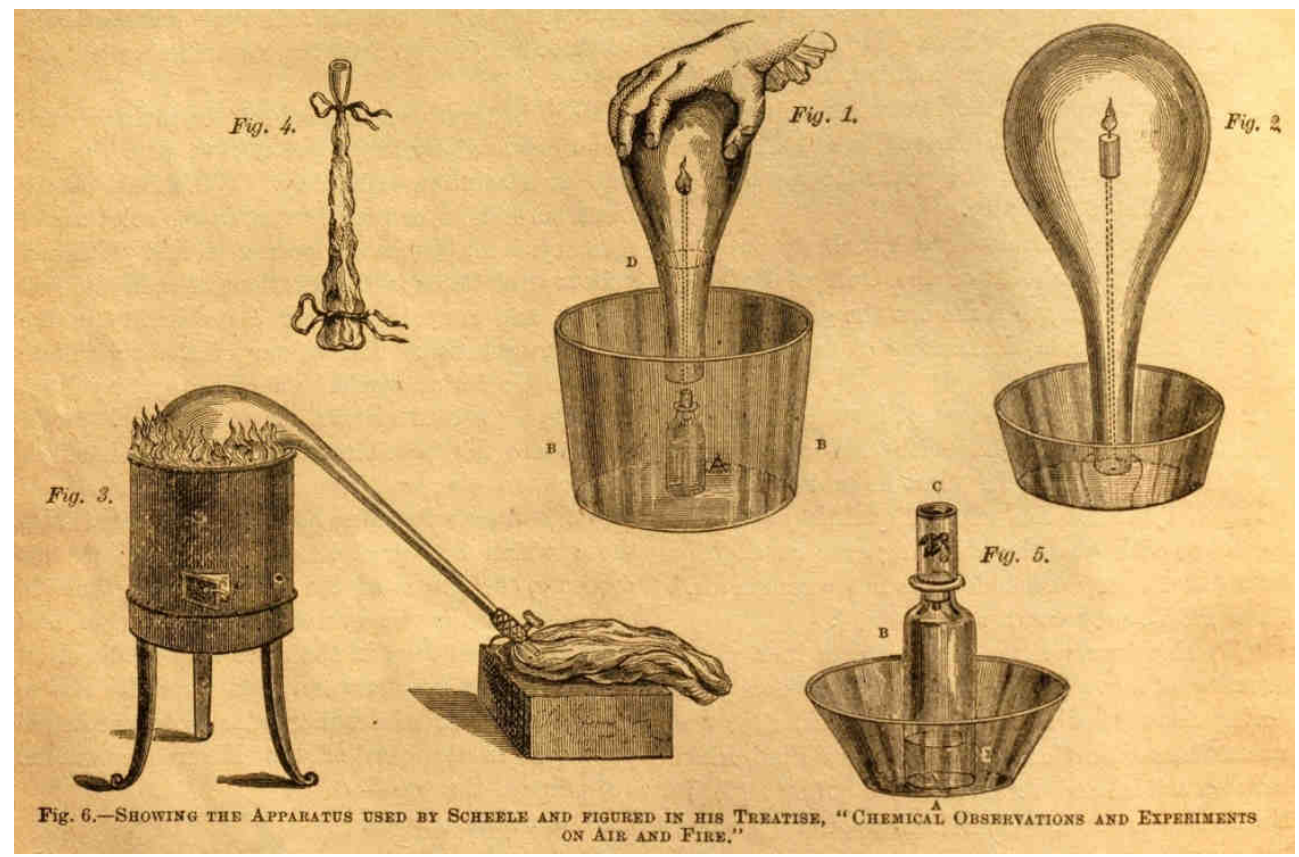

Fig. 14. Scheele's apparatus [11]

On this diagram, Figure 3 shows a furnace with retort flask containing calx of mercury, which decomposes to give fire air (oxygen), which is collected in the bladder, and liquid mercury which remains in the flask. It is interesting to note Figure 5. Vessel $\mathrm{C}$ is filled with fire air and the bottom of bottle B contains lime water. A bee is placed inside vessel $\mathrm{C}$ and is given some honey for food. After 6 days the bee dies and the lime water rises to fill vessels $\mathrm{B}$ and $\mathrm{C}$, and turns milky.

Antoine Laurent Lavoisier [1743-94] invented no new apparatus, devised no new experimental techniques and discovered no new substances. His genius lay in his ability to synthesize the work of others and recognise the importance of accurate quantitative work. Like Priestley he experimented with the calx of mercury and prepared the same gas which Priestley had named dephlogistigated air. Figure 15 shows the apparatus which he used. Flask A would have contained about $500 \mathrm{~cm}^{3}$ of mercury (weighing approximately $7 \mathrm{~kg}$ ) and in the trough RS and bell jar Q, there would have been water. To make a flask like this 
would have required great skill on the part of the glassblower! The furnace MN would have been capable of burning a fire for several weeks.

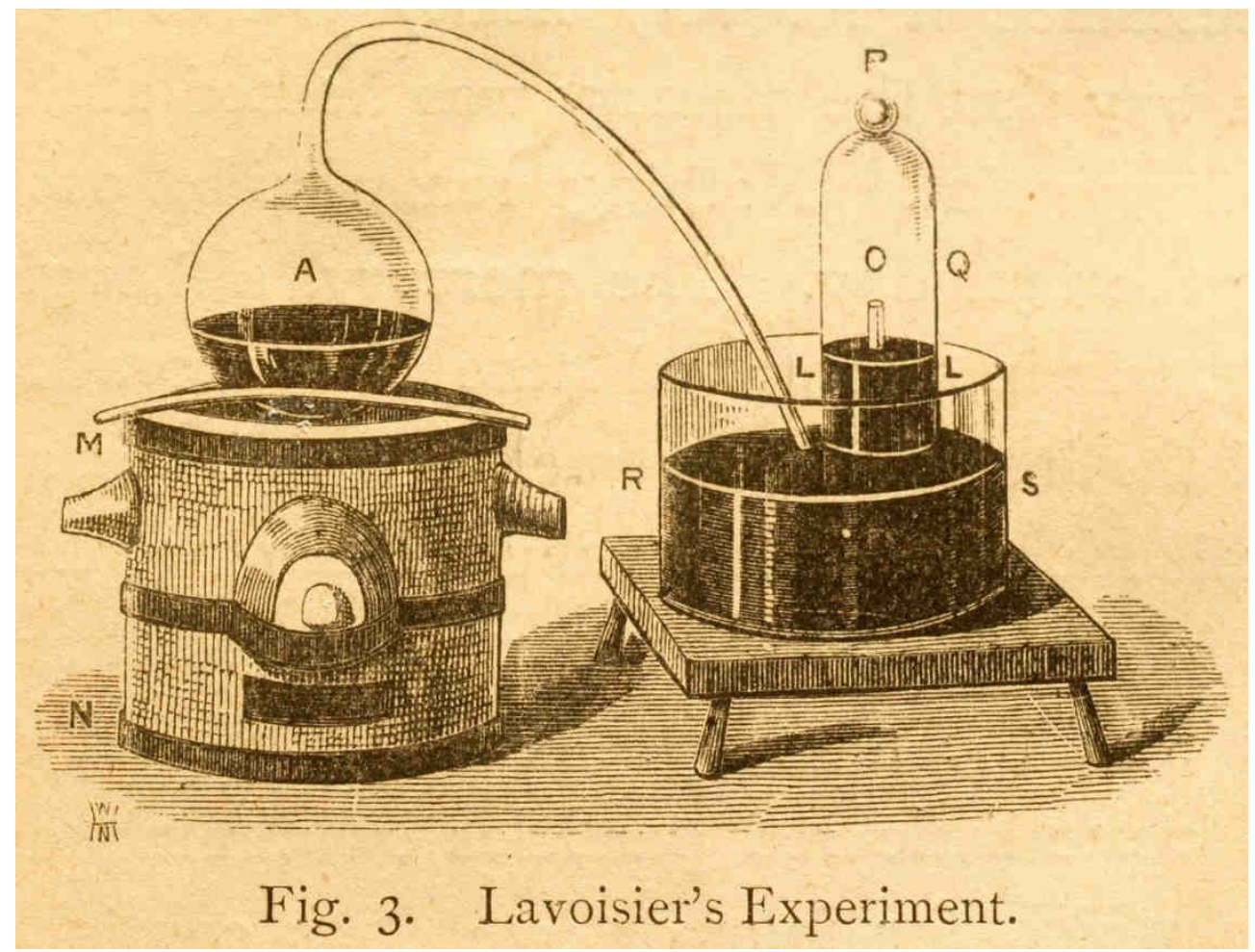

Fig. 15. Lavoisier's apparatus for the preparation of oxygen [12]

Lavoisier named this gas oxygen (I give birth to acids, gr. oksys = acidic; gr. gennao $=$ to give birth) and explained its role in combustion and respiration in a manner which remains substantially unchanged today:

During combustion, substances combine chemically with oxygen to form oxides.

Figure 16 shows Lavoisier with his wife Marie-Anne, who drew illustrations for his books. The most important of these was his Traité élémentaire de Chimie [1789], in which he summarized all his new theories.

After Lavoisier had realised the importance of oxygen, chemistry could be explained in terms of the combination of elements and compounds (synthesis), and the breaking down of compounds (decomposition). It is here, with the history of fire reaching a grand milestone, that modern chemistry begins.

Lavoisier was guillotined during the French Revolution, on $8^{\text {th }}$ May 1794. 


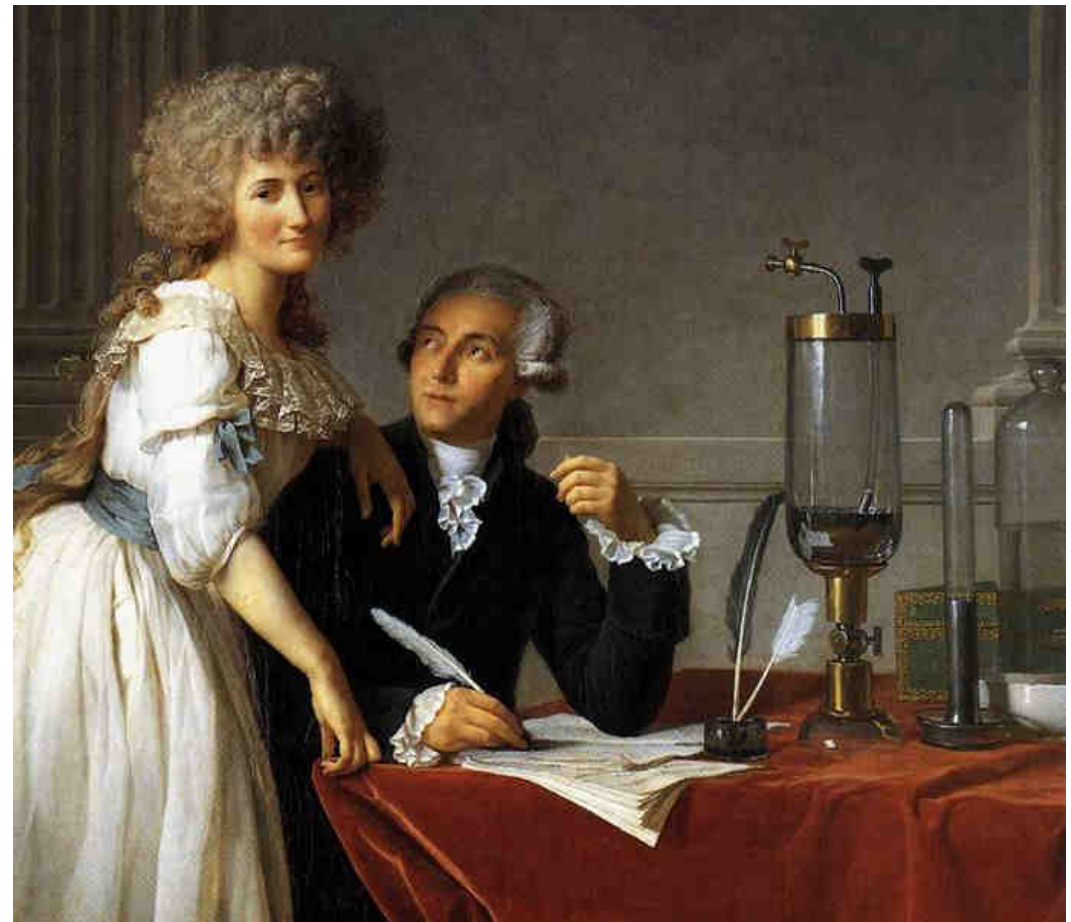

Fig. 16. Lavoisier with his wife Marie-Anne, who drew illustrations for his books (Detail of a portrait by Jacques Louis David, painted in 1788)

\section{Conclusion}

Just 30 years after Lavoisier's great synthesis, an early chemical dictionary was published. Figure 17 is a photograph of the entry for GAS (oxygen). It gives a succinct summary of the history of oxygen in 1808 - few such summaries exist today!

There is no better way to educate young people than to fill them with awe and amazement for the achievements of science, and the remarkable people who made these achievements possible. By telling the story of the history of fire, teachers will certainly achieve this aim. Even if time does not permit for the teaching of much detail, then the following highlights will at least do justice to this most important fragment of our culture: the history of fire.

1. It is not obvious that air is a mixture of gases.

2. From early experiments on burning until the publication of Lavoisier's theory of combustion, almost 2000 years elapsed.

3. Many brilliant scientists investigated fire. They were all extraordinary individuals from widely diverse backgrounds, and with a remarkable variety of life stories.

4. Discovering oxygen and its role in combustion was very difficult.

Figures 18 and 19 show school experiments on combustion. 
GAs (OxIGEN). This gas was obtained by Dr. Priestley in 1774 from red oxide of mercury exposed to a burning lens, who observed its distinguishing properties of rendering combustion more vivid and erninently supporting life. Scheele obtained it in different modes in 1775 ; and in the same year I.avoisier, who had begun, as he says, to suspect the absorption of atmospheric air, or of a portion of it, in the calcination of metals, expelled it from the red oxide of mercury heated in a retort. Priestley, agreeably to his theory, called it dephlogisti. cated air; Scheele, from its peculiar property, fire air, a name before given it by Mayon, or empyreal air; Lavoisier, air emi-

Fig. 17. An early history of the discovery of oxygen [13]

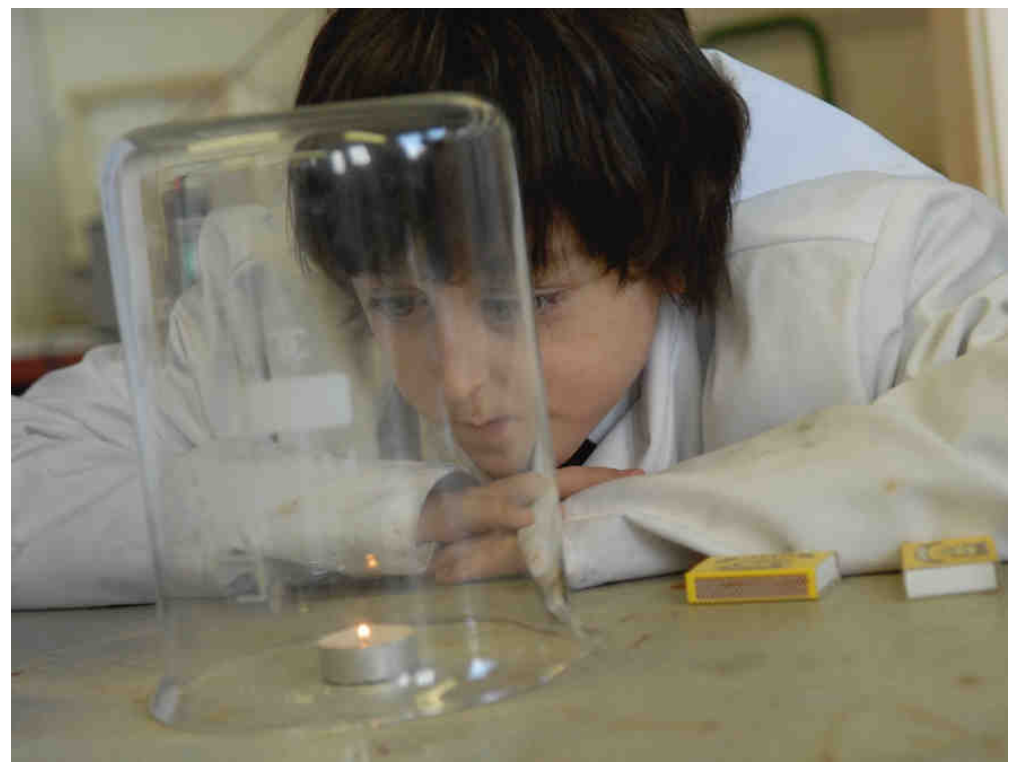

Fig. 18. School experiment - why does the flame go out? 


\section{Appendix}

Below are given details of a class practical, which I have successfully carried out with year 9 (13 year old) pupils. When conducting this experiment, it is the responsibility of the teacher to carry out an appropriate risk assessment.

\section{Gunpowder investigation}

Gunpowder was first used by Chinese technologists about 1200 years ago. It is a mixture of potassium nitrate, charcoal and sulphur, and was developed, probably from Greek fire, over a period of several hundred years, before the evolution of modern chemistry. This was a process of trial and error - gunpowder was continually modified until its combustion products could be released with maximum violence. There is no doubt that this explosive has shaped the path of world history - see the excellent book entitled Gunpowder by Jack Kelly (2004).

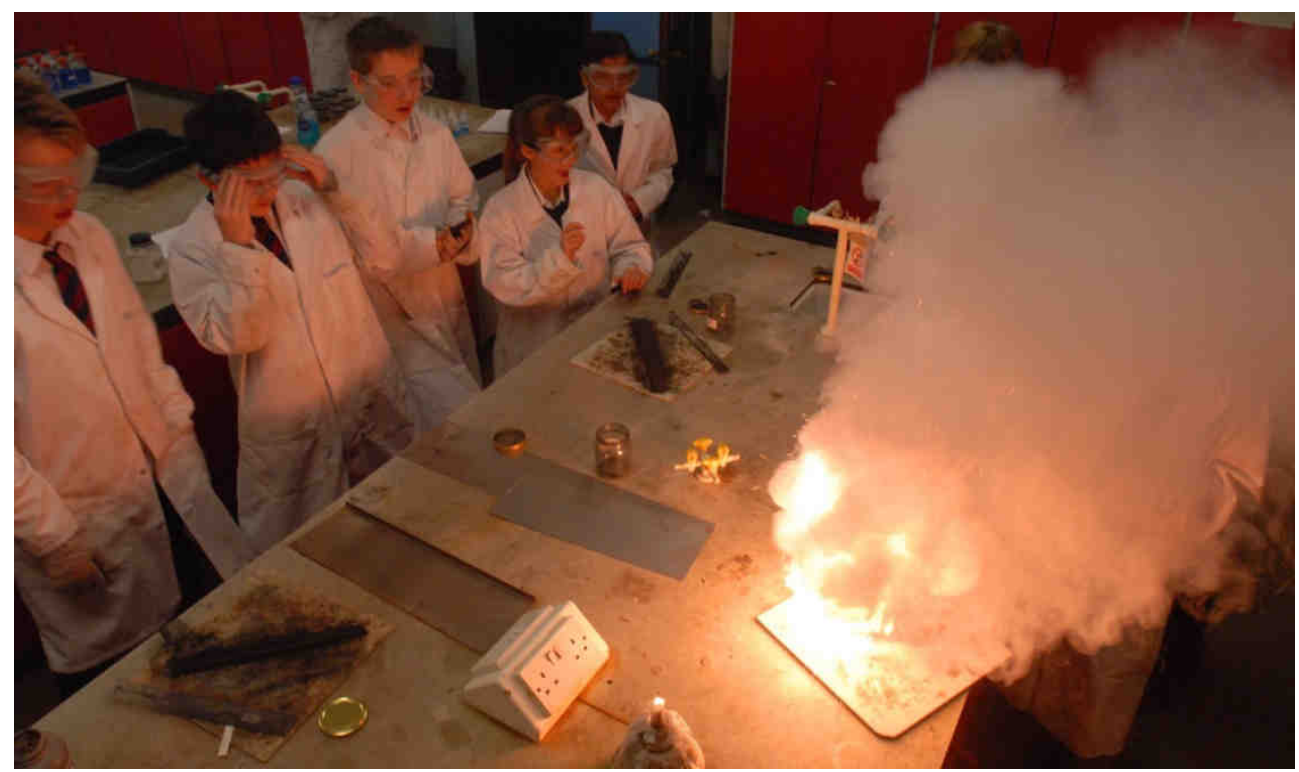

Fig. 19. School experiment: gunpowder investigation

In today's exercise, you shall make a sample of crude gunpowder (popularly known as "serpentine powder") and test its effectiveness by igniting your sample and seeing how it burns. The students whose powder burns most efficiently (i.e. the fastest) will win first prize. There are 3 criteria for making a successful gunpowder:

1. Mixing exactly the right proportions of potassium nitrate (oxidant), sulphur and charcoal (two non-metal elements, which are the fuels). The composition by mass of gunpowder is: $75 \%$ potassium nitrate, $15 \%$ charcoal and $10 \%$ sulphur.

2. Ensuring that the components are very finely powdered i.e. in a state of maximum subdivision, which gives the maximum surface area. 
3. Ensuring that the components are very thoroughly mixed - this ensures that there is maximum surface area of the particles in contact with one another.

\section{Instructions}

Wear vinyl gloves, safety specs and a lab coat throughout this experiment.

1. Weigh out $25 \mathrm{~g}$ of potassium nitrate and place it into a clean dry mortar. Grind the salt thoroughly for about 5 minutes, until it has the consistency of flour. (Industrially, this process lasts for 24 hours!). Do not grind the potassium nitrate with any other substance, since there is a serious risk of explosion. Pour the potassium nitrate onto a sheet of white paper and then carefully pour it into a clean glass bottle.

2. Weigh out the correct proportions of sulphur and charcoal (you will have to calculate these) and place them onto a sheet of A4 paper.

3. Gently grind the charcoal and sulphur together in the mortar in order to break up any lumps and add them, via a sheet of white paper, to the potassium nitrate in the bottle.

4. Place the lid on the bottle and shake it vigorously for a few minutes. Your serpentine powder is now ready for testing.

\section{The test}

In a fume cupboard, or out of doors, lay a trail of your powder, $30 \mathrm{~cm} \mathrm{long,} \mathrm{on} \mathrm{your}$ mild steel strip. Ignite the trail at one end using a burning splint and, using a stop clock, measure the time taken (to the nearest $0.1 \mathrm{~s}$ ) for the trail to burn. The team of students whose fuse burns the fastest will be the winners.

\section{Theory}

No exact equation for the combustion of gunpowder has ever been written (can you think why?), but a simplified equation is given below:

$$
\mathrm{KNO}_{3}+\mathrm{S}+\mathrm{C}=\mathrm{K}_{2} \mathrm{CO}_{3}+\mathrm{K}_{2} \mathrm{~S}+\mathrm{CO}_{2}+\mathrm{CO}+\mathrm{N}_{2}
$$

1. Can you balance this equation?

2. Using the balanced equation calculate the masses of potassium nitrate, sulphur and charcoal which ought to be mixed. Are these in the same ratio as mixture which you used?

(Atomic weights: potassium 39, nitrogen 14, oxygen 16, sulphur 32, carbon 12.)

\section{List of materials for gunpowder investigation}

4 solids reagent bottles of flowers of sulphur and 4 of willow charcoal,

6 balances,

4 reagent bottles of potassium nitrate,

splints,

matches.

\section{Per pair of pupils}

2 sheets A4 paper,

2 pairs of vinyl gloves, mortar and pestle

1 mild steel strip, $40 \mathrm{~cm} \times 10 \mathrm{~cm}$, or ceramic mat $30 \mathrm{~cm} \times 30 \mathrm{~cm}$,

1 large spatula, 
1 glass mixing bottle (e.g. jam jar) with screw cap,

3 large weighing boats,

1 stop clock.

\section{References}

[1] Werner ETC. Chinese weapons. Cambridge: Cambridge University Press for the Journal of the Royal Asiatic Society of Great Britain and Ireland (North China Branch) Extra volume;1933.

[2] Ercker L. The Laws of Art and Nature. Frankfurt; 1574. (Courtesy of the Wellcome Institute Library, London).

[3] Sendivogius M. The new chemical light. Calgary: Theophania publishing; 2011. ISBN: 9781468025514.

[4] Szydło Z. Water which does not wet hands: the alchemy of Michael Sendivogius. Warszawa: Polish Academy of Sciences; 1994, 115. ISBN: 8386062452.

[5] Boyle R. New experiments. physico-mechanical, touching the spring of air, and its effects. London: Richard Davis; 1682.

[6] Drebbel C. Van de natuyre der elementen. Amsterdam: 1688. (Courtesy of the Wellcome Institute Library, London).

[7] Partington JR. Everyday chemistry. London: Macmillan; 1938

[8] Mayow J. Tractatus quinque medico-physici. Oxford: 1674.

[9] Boerhaave H. Elementa chemiae quae anniversario labore docuit, in publicis, privatisque, scholis. Lugduni Batavorum: Isaac Severius; 1732.

[10] Priestley J. Experiments and observations on different kinds of air. London: J.Johnson; 1775.

[11] Brown R, editor. Science for all, pictorial marvels \& wonders in Nature vol. 2. London, Cassell \& Company, c. 1880 .

[12] Hartley WN. Air and its relations to life. London: Longmans Green \& Co; 1876.

[13] Nicholson W. A dictionary of practical and theoretical chemistry. Richard Phillips; 1808.

\section{Bibliography}

[1] Brzezinski R, Szydlo Z. A New Light on Alchemy. History Today. 1997;47(1):17-23.

[2] Bugaj R. Saletra filozofów a odkrycie tlenu (Philosophers' saltpetre and the discovery of oxygen). Kwartalnik Historii Nauki i Techniki. 1986;(3-4):751-80.

[3] Evans RJ. Rudolph II and his World. London: Thames and Hudson; 1997. ISBN: 0500279861.

[4] Frank Jr RG. Harvey and the Oxford Physiologists. Berkeley, Los Angeles, London: University of California Press; 1980. ISBN: 0520039068.

[5] Prinke R. Alchemical Patronage and the Making of an Adept. Ambix. 2018;65(4):324-55.

[6] Prinke R. Michał Sędziwój - początki kariery (Early career of Michael Sendivogius). Kwartalnik Historii Nauki i Techniki. 2012;(1):89-129.

\section{Suggestions for further reading}

[1] Cressy D. Saltpeter the Mother of Gunpowder. Oxford: Oxford University Press; 2013. ISBN: 9780199695751.

[2] Kelly J. Gunpowder. New York: Basic Books; 2004. ISBN: 1843541912.

[3] Partington JR. A Short History of Chemistry. London: Macmillan; 1965.

[4] Read J. Through Alchemy to Chemistry. A procession of ideas \& personalities. London: G. Bell; 1957.

[5] Temple R. The Genius of China. New York: Simon and Schuster; 1986. ISBN: 0671620282.

[6] Tilden W. Famous Chemists and their Work. London: George Routledge \& Sons Ltd; 1935.

\section{Demonstration lecture}

YouTube: Szydlo Andrew. "Fireworks \& Waterworks", Royal Institution of Great Britain. $17^{\text {th }}$ Feb. 2016, 29-39 minutes. 